\title{
The Efl Teachers' Teaching Methods At SMPIT Tunas Cendekia Mataram
}

\author{
Imansyah \\ Faculty of Culture, Management, and Business UNDIKMA Mataram
}

Email: imansyah022@gmail.com

\begin{abstract}
This descriptive qualitative research was aimed at finding out the methods employed by the EFL Teacher at SMPIT Tunas Cendekia Mataram. The setting of the research was in SMPIT Tunas Cendekia Mataram. The subject of this research was the $7^{\text {th }}$ grade EFL teacher consisting of one single teacher. This research was designed as a descriptive qualitative research. The data were collected through, interview and document study (lesson plan). Data was analyzed by using the theories proposed by Larsen-Freeman (1986) and Richards and Rodgers (2001) classification. In relation to problem raised, the study identifed that there were three methods the teacher employed in the teaching process. They were Community Language Learning, Direct Method, and Audio-Lingual Method. Community Language Learning was employed five (5) times for five (5) different meetings, Direct Method was employed two (2) times for two different meetings, and Audio-Lingual Method was employed one (1) time.
\end{abstract}

Keywords: Teaching Methods

\section{INTRODUCTION}

\section{Background of the study}

According to Kunandar (2007), teacher plays important role as the basic element in teaching and learning. As a professional educator, teacher is responsible to educate, teach, supervise, direct, train, assess, and evaluate learners (Depdiknas, 2005). For this reason, teacher should be able to design a comfortable and conducive class atmosphere that will make the students enjoy and learn the material at the same time so that the learning goal can be met. As students' characteristics and background vary, it is very important for teacher to carefully select the right method implemented in order to assist the students achieve the learning goal. Therefore, a carefully designed procedure is primary in teaching and learning activities. In other words, teacher needs a certain method to reach a certain goal in teaching and learning.

How the teacher makes the students learn and achieve a certain goal cannot be separated from the success of the students in learning English. The learning goal can be achieved if teacher and students can work together to go to the same end through the way that has been planned and designed by the teacher, i.e., method, to make the students easy to learn along the way.
According to Orlich, et al., (2010), deciding which teaching methods applied in the class requires a thoughtful design and planning. In teaching, teacher is dealt with a group of different individuals that come from different backgrounds and the goal of teaching itself is to bring those differences together into the learning (Silver, Harvey F., Richard W. Strong, and Mathew J. Perini, 2007). Therefore, teacher should take into account the goal/s that she wants the students to achieve.

Celce-Murcia (2001) believe that there have been development and changes of approaches and methods over the years in second or foreign language teaching. A lot of approaches and methods are available to be suited and used as the basic for teaching and learning in language class. The methods rooted from approaches are abundantly varied. Lots of variations and techniques can be applied to reach the learning objectives. The learning objectives are the basic for the decision of what approach, method, and strategy that is going to be used in the process of teaching and learning.

Nowadays, EFL teachers are required to have the knowledge and skills of various teaching methods as the focuses of English language teaching in high School are students' ability to understand and produce 
oral and written texts in relation to four language skills, students' competence to comprehend short functional texts and monologues, linguistic competence (grammar, vocabulary, spelling, and written rules), cultural competence (language expression based on the community context), and strategic competence (Depdiknas RI, 2006). There have been some lists of methods in EFL pedagogy that are developed to facilitate English language learners. Those methods sometimes are modified from the classical ones or breakthrough. Celce-Murcia (2004) explains types of methods that are commonly used in the four language skills. Furthermore, Richard and Rogers (2001) have listed seven methods that can be used for teaching English as a foreign language.

Related to that issue, researcher was inspired to investigate the teaching methods employed by EFL teacher in SMPIT Tunas Cendekia Mataram as it was very essential for the teacher to have good understanding on the methods of teaching so that they could choose the best methods to achieve the goals set.

\section{Significances of the Study}

The results of this research will be beneficial for some parties. They are:

1. For the school institution, the result of the study can be used to give picture on how the teaching methods implemented in the language classes and how to handle the problems encountered when implementing the methods.

2. For the teachers in SMPIT Tuns Cendekia Mataram, this study will be used as a reflection for their own teaching.

3. For the English teachers in general, this study will give insight about the EFL teaching methods that are used in high school and maybe the methods can be used in their own classes.

\section{REVIEW OF RELATED LITERATURE Teaching Methods}

Brown (2001) describes method as an overall plan for systematic presentation of language based upon a selected approach. It is more specific than an approach, but less specific than a technique. Methods are typically compatible with one (or sometimes two) approaches (Celce-Murcia, 2001). It is the level at which theory is put into practice and at which choices are made about the particular skills to be taught, the content to be taught, and the order in which the content will be presented (Richards and Rodgers, 2001).

The followings are the methods that are currently practiced today.

\section{Grammar Translation Method}

The first aim of GTM was to help students read foreign language literature. It was hoped that by studying grammar of the target language students would become familiar with grammar of their native language and also the target language. According to Larsen-Freeman (1986), the purposes of learning foreign language based on GTM are: to be able to read literature written in the target language; to provide students with good mental exercise which helps develop their minds; to give the learners grammatical rules and examples to memorize them; to make them apply the rules to other examples; to teach the students to write in both their native and the target languages through translation.

Furthermore, Larsen-Freeman (1986) states the basic principles of GTM. Those principles are: characteristic interaction in the teaching process is a Student - Teacher interaction; the teacher is the authority in the classroom; literary language is considered superior to spoken language, culture is considered as consisting of literature and the fine arts, behavior culture is ignored; passive vocabulary and grammar are emphasized at cost of pronunciation; reading and writing are the primary skills much less attention is given to speaking and listening; the language that is used in class is mostly the students native language, the meanings of new words are made clear by translating them into the students native language; evaluation is accomplished on the basis of 
written tests in which students are expected to translate from their native language to the target one or vice versa, questions about the foreign culture have to be answered as well; culture is viewed as consisting of literature and the fine arts; error correction is very important, the teacher always supplies the students with the correct answer; and the syllabus is structure-based

Activities that are characteristic of the method are: translation of a literary passage, reading comprehension, finding antonyms and synonyms, using words in sentences, gap-filling exercises, memorization, and compositions.

\section{Direct Method}

In Direct Method, no translation is allowed. Based on this method, meaning is connected directly with the target language without going through the process of translating into the native language (Richards and Rodgers, 2001). The goal of language learning is communication. Therefore, to achieve that goal, students should learn to think in the target language. Teacher should demonstrate not explain the meaning and the students should be encouraged to speak as much as possible. Through this method, students also learn the culture of the target language because learning a language involves learning the behavior culture of the people in which they live (Larsen-Freeman, 1986).

Examples of activities based on this method are: reading aloud, conversation practice, gap filling exercise, dictation, map drawing and paragraph writing.

3. Audio-lingual Method

The goal of Audio-Lingual Method is to enable students to use the target language communicatively. The characteristics of this method, according to Larsen-Freeman (1986), are: the teacher is like an orchestra leader, directing and controlling the language behavior of her/his students; she provides her students with a good model for imitation; the target language is used in the classroom not the students' native language; there is student- student interaction in chain drills or when students take different roles in dialogues, but this interaction is teacher-directed because most of the interaction is between teacher-student and is initiated by the teacher; new vocabulary and structures are presented through dialogues, the dialogues are learnt through imitation and repetition, grammar is induced from the examples given: explicit grammar rules are not provided; cultural information is contextualized in the dialogues or presented by the teacher; the oral/aural skills receive most of the attention, pronunciation is taught from the beginning, often by students working in language laboratories; students are evaluated on the bases of distinguishing between words in a minimal pair or by supplying an appropriate word form in a sentence; student errors are to be avoided through the teacher's awareness of where the students will have difficulty; and the syllabus is structure-based.

The activities that can be done based on this method are: dialogue memorization, expansion-drill, repetition drill, chain drill, single-plot substitution drill, multiple-slot substitution drill, transformation drill, question and answer drill, use of minimal pairs, gap-filling and grammar game.

4. The Silent Way

The Silent way is a method of language teaching in which the teacher should be silent as much as possible in the classroom, but the learners should be encouraged to produce language as much as possible (Richards and Rodgers, 2001). In this method, student-student verbal interaction is desirable and encouraged. The teacher only speaks to give clue and instruction to the students. The native language can be used to give instruction when necessary. All of four skills are worked out from the beginning of the course. The culture is also seen as inseparable with the language (LarsenFreeman, 1986).

The activities that characterized this method are: sound-color char, peer 
corrections, teacher's silence, rods, selfcorrection game, word chart, field chart, and structured feedback.

5. Suggestopedia

The goal of the method is to accelerate the process by which students learn to use a foreign language for everyday communication. This is to be done by breaking down the psychological barriers learners bring with them to the learning situation. The most conspicuous characteristics of suggestopedia are the decoration, furniture, and arrangement of the classroom, the use of music and the authoritative behavior of the teacher (Richards and Rodgers, 2001).

Larsen-Freeman (1986) explains the principles of Suggestopedia. Those principles are: the teacher is the authority in the classroom, who must be trusted and respected by the students - once the students trust the teacher, they feel secure, they can be more spontaneous and less inhibited; all types of interactions are to be found in case of the method, however first it is the teacher that initiates interactions with the whole group of students and with individuals right from the beginning of a course; in the beginning of the course the students can only respond nonverbally, later the students have more control of the target language and can respond more appropriately, and even initiate interaction themselves. Students interact with each other from the beginning in various activities directed by the teacher; native language translation is used to make the meaning of the dialogue clear, the teacher uses the mother tongue in lesson when necessary; as the course proceeds, the teacher uses the native language less and less; vocabulary is emphasized, the success of the method can be put down to the large number of words that can be acquired; grammar is dealt with explicitly but minimally, students will learn best if their conscious attention is focused not on the language forms but on using the language; pronunciation is developed by reading out loud; the culture which students learn concerns the everyday life of people who speak the language. The use of the fine arts is also common in Suggestopedia; speaking communicatively is emphasized, students also read the target language and write, for example compositions; evaluation is conducted on students' normal in-class performance and not through formal tests; at the beginning levels, errors are not corrected immediately since the emphasis is on students communicating their intended meaning; and when errors occur the teacher uses delayed correction.

The activities that include in this method are: peripheral learning, choose a new identity and role play.

6. Community Language Learning

Community Language Learning (CLL) is a method developed by Charles A. Curran. He was a specialist in counseling and a professor of psychology. He applied the theory of counseling in language learning. Therefore, in this method, teacher is said as the counselor because she is the one who understands the language and the difficulties faced by the students in learning the target language. And the students here are called as clients as they consult to the teacher whenever they face problems and need for solutions (Richards and Rodgers, 2001: 90).

The activities that based on this method are as follows: transcription, human computer, reflective listening and small group tasks.

7. Total Physical Response

TPR is a language teaching method built around the coordination of speech and action, and it attempts to teach language through physical (Richards and Rodgers, 2001). The TPR was developed to reduce the stress that the people feel when learning foreign languages and engage students to study beyond the beginning level of proficiency. 
The principles of TPR according to Larsen-Freeman (1986) are: the teacher is the director of all students' behavior and the students are the imitators of her nonverbal model; interaction is between the teacher and the whole group of students and with individual students; spoken language is emphasized over written language; pronunciation is developed through listening mostly; and grammatical structures and vocabulary are emphasized over language area.

The activities included in this method are: using command to direct behavior, role reversal, and action sequence.

\section{RESEARCH METHOD \\ Research Design}

This research used qualitative descriptive method to describe the methods implemented by the EFL teachers in English teaching process. The subject of this research was the $7^{\text {th }}$ grade EFL teacher at SMPIT Tunas Cendekia Mataram. Document study and interview were conducted to gain the data. Through document study, the researcher found the data about teaching methods employed in the teaching. Through interview, the researcher found data of how and why they employed certain methods in the teaching process. Data were then analyzed by reducing, displaying, and drawing conclusion of the data.

\section{RESEARCH FINDING AND DISCUSSION}

This research was conducted for 4 weeks, from the second week of July to the second week of August. 8 lesson plans were taken as the source of data. From the lesson plan, the researcher found out the methods the EFL teachers selected and employed to be used in the teaching process. There were at least three different methods employed by the EFL teacher, they were Audio lingual method, community language learning, direct method.

Audio-Lingual Method was used only once and at the $4^{\text {th }}$ meeting. As the lesson began, the teacher informed the students about the expected learning outcomes to make students aware about what they would learn during the lesson. After explaining the learning outcomes, the teacher played the audio and the students listen to it. the lesson was about address and country (focused on asking and answering questions related to greetings and introduction). While listening, the students were asked to answer simple questions related to the audio. She then played the audio one more time to let the students check their own answer. After that, she confirmed whether the students' answers were correct or not. After discussing the students' work, she demonstrated how people greet each other. She asked her students to repeat after her. She did it for several time. The teacher believed that the more the students repeat it, the stronger the habit and the greater the learning. It is in line with Larsen-Freeman (1986) saying that language learning is seen to be a process of habit formation.

Later in the lesson, the teacher had the students work in pair to make a dialogue to practice the language expression they learned at that time. The teacher gave students feedback on their work, corrected the mistakes they made, and gave reinforcement to their work. This is in line with the principle of Audio-Lingual Method that spoken form is more basic to language than the written one (Larsen-Freeman, 1986).

The next method employed was Community Language Learning. This method was employed for around five times for five different topics. In meeting 5, the teacher employed this method to teach the students how to ask and answer questions related to countries and city they were from. As usual, before she began the lesson, she told the students about the competencies being taught at that time. She also explained the expected outcome so that the students would be aware of the things they were about to learn. This is consistent with the principle of Community Language Learning that students learn best when they feel secure (Larsen-Freeman, 1986). After explaining the learning outcomes, the teacher then asked the students where they were from. The students answer the question one by one. The teacher did it for several time to several different student. 
According to the teacher, she did it to show the students how to ask questions about someone's address (origin). After that, the teacher, along with the students highlighted some expressions they might feel comfortable to use when they want to find out someone's origin. After several exercises, the teacher asked the students to practice by making dialogue. The teachers emphasized that they could choose and use any expression that fit them. As the students practiced the dialogue, the teacher corrected the students' mistake (when necessary) and gave reinforcement to their work. At the end of the lesson, the teacher asked the students about the topic learned. What was missing from this lesson was that the teacher forgot to ask about how the students felt about the lesson they learned. As Larsen-Freeman (1986) believes that asking how they feel is one of the keys to understand the students so that they can feel accepted as whole persons. Consequently, they will feel comfortable and enjoy the lesson being taught. This matter rose simply because the teacher had insufficient knowledge about how to employ the method well. For the next meetings $(7,8,10$, and 11$)$, the teacher repeated the same steps she did in meeting 5. She commenced the lesson by providing information about the topic they would learn during each lesson, and provided opportunities for students to practice the lesson with their own comfortable style. The absent of asking how the students' feeling about the lesson also happened here. As has been mentioned before, this could happen simply because the teacher had lack of understanding to implement the method properly.

Direct method was employed at the $6^{\text {th }}$ meeting when the lesson was about how to express and identify time. As has been her usual, informing the learning outcomes became the first thing she did to commence the lesson. After that, she started to pose question to students to trigger their motivation. She asked "what time is it now? The students replied in chorus "10". She then told her students to answer in complete sentence. She asked another question related to time to each student. The students tried to answer the questions in complete sentence. She, along with the students, highlighted some expressions related to asking and telling time. She then provided more examples of how to ask and tell time. She used a clock that was made of board to help the students understand the lesson better. For exercise, she pointed one student to stand in front of the class and set the time on the board clock. The student should ask what time and the class should answer it. the activity went on for several minutes to several students. During the lesson, the teacher tried to avoid the use of Indonesian language and employed target language, i.e English as much as possible as she was aware that employing this method requires teacher to engage the students with the target language and avoid the use of translation and/or the Indonesian language. At the end of the lesson, the teacher asked the students about what they had learned and what they hadn't understood yet. This was meant to find out if the learning goals were achieved or not.

\section{CONCLUSION AND SUGGESTION Conclusion}

Based on the findings, it is seen that there were three different methods that were employed by the EFL teacher. They were Community Language Learning, Direct Method, and Audio-Lingual Method. Community Language Learning was employed five (5) times for five (5) different meeting, Direct Method was employed two (2) times, and Audio-Lingual Method was employed one (1) time.

\section{Suggestion}

In relation to the finding of the research, the researcher proposes some suggestions

1. Based on the result of the findings, it is suggested that the next research should be conducted regarding the absent methods in the teaching process.

2. Teacher at SMPIT Tunas Cendekia Mataram should apply methods providing 
opportunities for students to be more engaging during the learning process.

3. It is suggested for EFL teachers in SMPIT Tunas Cendekia Mataram to enhance her teaching quality by joining more seminars related to strategies in language teaching.

\section{REFERENCES}

Brown, Douglas H. (2001). Teaching by Principles: An Interactive Approach to Language Pedagogy, $2^{\text {nd }}$ Edition. San Francisco: Addison Wesley Longman, Inc.

Celce-Murcia, Marianne. (2001). Teaching English as a second or Foreign Language, third edition. USA: Heinle $\&$ Heinle Thomson Learning Inc.

Depdiknas RI. (2006). Pedoman Kurikulum Tingkat Satuan Pendidikan untuk Sekolah Menengah Atas Tahun 2006. Jakarta: Depdiknas RI.

Depdiknas. (2005). Undang-Undang Republik Indonesia Nomor 14 Tahun 2005 Tentang Guru dan Dosen. http://luk.staff.ugm.ac.id/atur/UU142005GuruDosen.pdf. Accessed on April 12th, 2012.

Larsen-Freeman, Diane. (1986). Technique and Principles in Language Teaching. Oxford University Press.

Orlich, Donald C., Robert J. Harder, Richard C. Callahan, Michael S. Trevisan, and Abbie H. Brown. (2010). Teaching Strategies: A Guide to Effective Instruction. Boston: Wadsworth, Cengage Learning.

Richards, Jack C., and Theodore S. Rodgers. 2001. Approaches and Methods in Language Teaching. USA: Cambridge University Press.

Silver, Harvey F., Richard W. Strong, and Mathew J. Perini. (2007). The Strategic Teacher: Selecting the Right Research-Based Strategy for Every Lesson. USA: Thoughtful Education Press. 